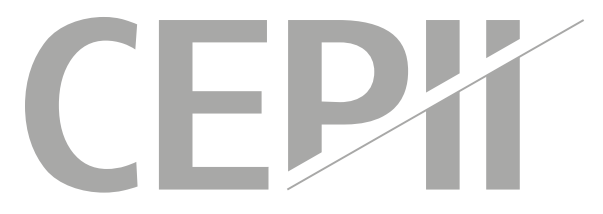

\title{
Risk Shocks and Divergence between the Euro Area and the US in the aftermath of the Great Recession
}

Thomas Brand \& Fabien Tripier*

\section{Highlights}

【 Highly synchronized during the Great Recession of 2008-2009, Euro area and US economies have diverged since.

- This paper assesses the role of financial frictions and credit allocation to non-financial corporations in explaining the divergence observed between the two economies.

- A positive risk shock increases the volatility of idiosyncratic uncertainty in the financial sector making credit interest rate higher and corporate credit lower.

- Risk shocks dominate all other shocks in explaining the divergence after the financial crisis between the two economies.

- Risk shocks have stimulated US growth in the aftermath of the Great Recession and have been the main driver of the double-dip recession in the Euro area. 


\section{Abstract}

Highly synchronized during the Great Recession of 2008-2009, the Euro area and the US have diverged in the period that followed. To explain this divergence, we provide a structural interpretation of these episodes through the estimation for both economies of a business cycle model with financial frictions and risk shocks, measured as the volatility of idiosyncratic uncertainty in the financial sector. Our results show that risk shocks have stimulated US growth in the aftermath of the Great Recession and have been the main driver of the double-dip recession in the Euro area. They play a positive role in the Euro area only after 2015. Risk shocks therefore seem well suited to account for the consequences of the sovereign debt crisis in Europe and the subsequent positive effects of unconventional monetary policies, notably the ECB's Asset Purchase Programme (APP).

\section{Keywords}

Great Recession, Business cycles, Uncertainty, Risk Shocks, Divergence.

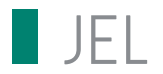

$\mathrm{E} 3, \mathrm{E} 4, \mathrm{G} 3$.

\section{Working Paper}

CEPII (Centre d'Etudes Prospectives et d'Informations Internationales) is a French institute dedicated to producing independent, policyoriented economic research helpful to understand the international economic environment and challenges in the areas of trade policy, competitiveness, macroeconomics, international finance and growth

CEPII Working Paper
Contributing to research in international
economics
@ CEPII, PARIS, 2021
All rights reserved. Opinions expressed
in this publication are those of the
author(s) alone.

Editorial Director: Sébastien Jean

Production: Laure Boivin

Published on 22.03.21

No ISSN: $1293-2574$
CEPII

20, avenue de Ségur TSA 10726 75334 Paris Cedex 07 +33153685500 www.cepii.fr Press contact: presse@cepii.fr 


\title{
Risk shocks and divergence between the Euro area and the US in the aftermath of the Great Recession ${ }^{1}$
}

\author{
Thomas Brand* and Fabien Tripier ${ }^{\dagger}$
}

\section{Introduction}

Highly synchronized during the Great Recession of 2008-2009, Euro area and US economies have diverged since. The former entered a new recession in the middle of 2011 while the latter pursued its expansion, as can be seen in Figure 1. ${ }^{2}$ The weak growth rate of real GDP per capita after the financial crisis and the absence of a catch-up phase in the US economy has initiated a debate on the origins of the slow recovery. ${ }^{3}$ But the US economy

\footnotetext{
${ }^{1}$ We wish to thank \%Benjamin Carton, Simon Gilchrist, Benoit Mojon, Natacha Valla and seminar participants at CEPII, CEPREMAP and GAINS - University of Maine. A companion website to this paper is available at $\backslash\{\}$ href $\{$ https://shiny.cepremap.fr/divergence-website $\}\{$ https://shiny.cepremap.fr/divergencewebsite\}.
}

*CEPREMAP, 48 boulevard Jourdan, 75014 Paris, France, thomas.brand@cepremap.org

†Université Paris-Saclay, Univ Evry, EPEE, 91025, Evry-Courcouronnes, France \& CEPII, fabien.tripier@univ-evry.fr

${ }^{2}$ The divergence is particularly striking given the strong similarity of the timing and the magnitude of the 2008-2009 recessions. The peak date is 2007Q4 for the US, and Euro area enters recession one quarter later, in 2008Q1, according to the NBER and the CEPR respectively. There is no difference in the trough dates, 2009Q2 for both, and the date of the second peak for the Euro area is 2011Q3. The cumulative loss of output between 2007Q4 and 2009Q2 is close to 5 percent in the Euro area and the US (5.2 and 5.0 respectively).

${ }^{3}$ See for instance Baker et al. (2012), Galí et al. (2012), Fatás and Mihov (2013) or Taylor (2014). 
still outperformed the Euro area economy, which experienced a second recession whose effects on GDP level are still felt ten years later. This paper assesses the role of financial frictions and credit allocation to non-financial corporations in explaining the divergence observed between the two economies.

The Euro area case corresponds to the pattern of a "double-dip recession" identified by Reinhart and Rogoff (2014) as typical after historically severe systemic banking crises. ${ }^{4}$ Sovereign debt market crisis in several European countries plunged the euro zone into a second recession between 2011-Q3 and 2013-Q1 using the $€ A C B N$ 's chronology. ${ }^{5}$ The divergence induced by this second recession is not limited to GDP or investment. Financing conditions for firms also differed-see Figure 1. In the Euro area, credit spreads on bank loans are durably higher than their pre-crisis level and only began to decrease after 2015 , at the same time as the term premium on government bonds. Net worth is also below its pre-crisis value. On the contrary, in the US, credit spreads returned to their pre-crisis values in 2014 while growth rates of credit and net worth have been higher than GDP growth, and much higher than in the Euro area. Based on such evidence, we investigate the role of the financing conditions for firms in explaining the divergence between the two economies.

\footnotetext{
${ }^{4}$ According to the authors a double-dip recession occurs after 2008 in several economies of the Euro area (France, Ireland, Italy, Netherlands, and Portugal) but not in all. Recessions in Germany, Spain, and Greece, which differ with respect to their amplitude and duration, have a single dip-see the online appendix of Reinhart and Rogoff (2014). Using the author's definition of a double-dip as "any renewed downturn that takes place before the economy reaches the prior peak", the Euro area as a whole experienced a double-dip recession and not the US for the business cycle reference dates provided before.

${ }^{5} \mathrm{~V}$ isit the EACBN dating committee webpage: https://eabcn.org/dc/chronology-euro-area-business-cycles and see Pisani-Ferry (2014) for an extended narrative.
} 
We first show that the volatility of idiosyncratic uncertainty in the financial sector, defined as risk shocks by Christiano et al. (2014), has played a crucial role in the US because they have stimulated credit and investment growth since the trough of 2009 whereas they have been at the origin of the double-dip recession in the Euro area. Such shocks have played a positive role in the Euro area only since 2015 and therefore seem well suited to account for the consequences of the sovereign debt crisis and the subsequent positive effects of unconventional monetary policies. Second, according to our results, differences in financial structures between the two economies have attenuated the divergence between the two economies implied by risk shocks.

Idiosyncratic uncertainty in the financial sector has been introduced in dynamic and stochastic general equilibrium (DSGE) models by Bernanke et al. (1999). More recently, Christiano et al. (2014) make this idiosyncratic uncertainty time-varying through risk shocks that modify the standard deviation of idiosyncratic shocks to the productivity of private borrowers and lead to macroeconomic fluctuations. ${ }^{6}$ By doing so, the authors provide a

\footnotetext{
${ }^{6}$ In this model, the entrepreneur combines personal wealth and loans provided by the financial intermediary to transform raw capital into effective capital. The technology to perform this transformation is specific to each entrepreneur and is approximated by an idiosyncratic shock applied to raw capital. Entrepreneurs who draw a low value of this idiosyncratic shock experience failure and lenders have to pay to check the state of the firm because of asymmetric information à la Townsend (1979). An increase in risk means a higher dispersion of idiosyncratic shocks and therefore a higher risk of default. The outcome of optimal financial contract is modified: the credit spread between the loan interest rate and the risk free interest rate rises to cover the higher risk taken by the lender and the leverage ratio of entrepreneurs falls to limit the size of financial losses. Entrepreneurs diminish their demand for physical capital leading to an aggregate reduction in investment and production. This countercyclical behavior of credit spread makes risk shocks different from financial shocks on the wealth of borrowers, also referred as equity shocks (Gertler and Karadi, 2011).
} 


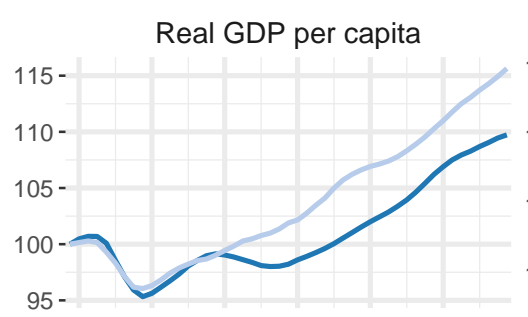

GDP deflator

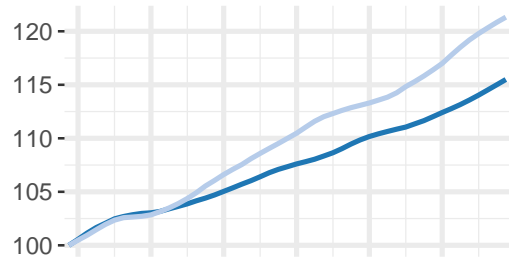

Hours worked per capita

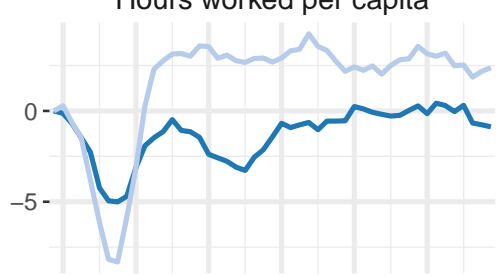

Short-term risk-free interest rate

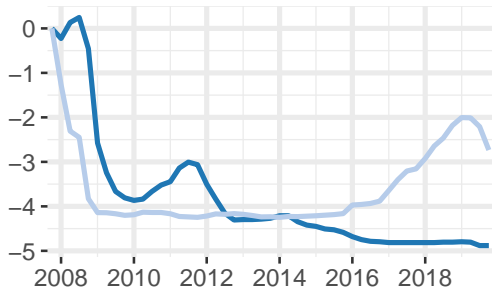

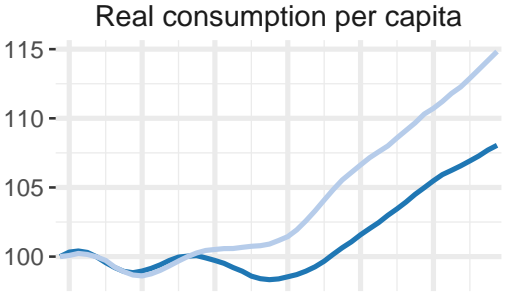

Real wage per capita
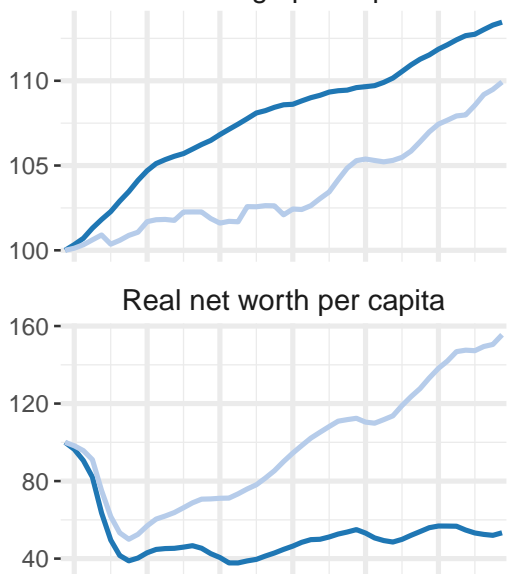

Term premium

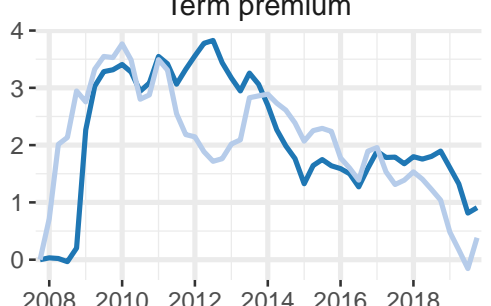

$2008 \quad 2010 \quad 2012 \quad 2014 \quad 2016 \quad 2018$

- Euro Area - United States

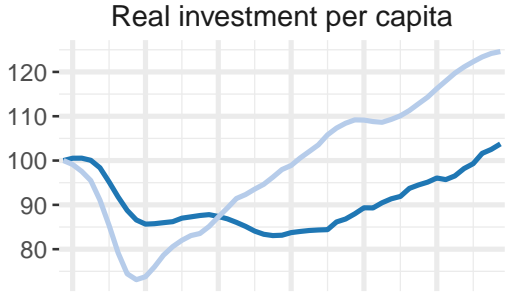

Real price of investment

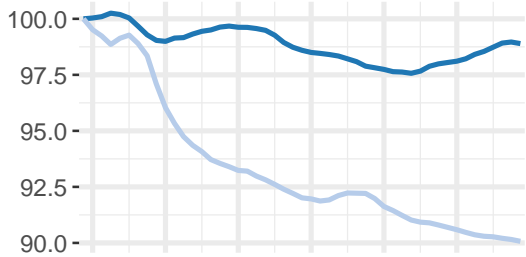

$90.0-$

Real credit per capita

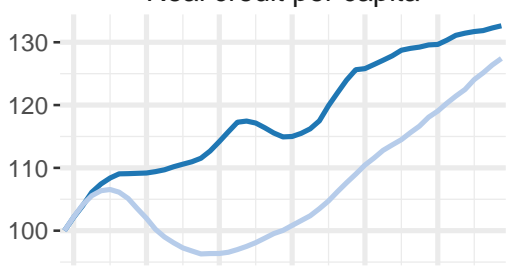

Credit spread

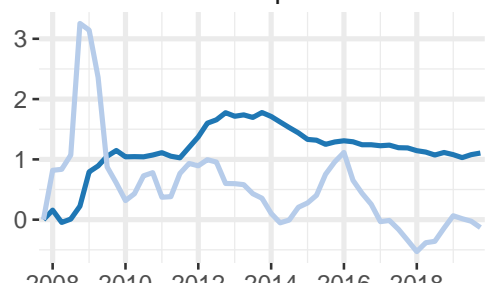

$2008 \quad 2010 \quad 2012 \quad 2014 \quad 2016 \quad 2018$

\section{Figure 1 - Comparison of variables between the Euro area and the US (2007Q4-2019Q4)}

Note: Index in base $100=2007$ 4, except for interest rates and spreads which are in deviation from 2007Q4 value in Annual Percentage Rate (APR) and Annual Percentage Points (APP) respectively. Source: See section 2.2.1.

new transmission channel of uncertainty to business cycles through financial frictions that we use in this paper. This new transmission channel has also been developed by Arellano et al. (2019) who consider changes in the volatility of idiosyncratic demand shocks between hiring decision and sales revenues. For reasons outlined below, we believe that to account for divergences in private investment, it is best to lay out a model which states explicitly the process by which physical capital accumulates. 
The transmission channel traditionally considered in the literature is a consequence of irreversible investment or fixed costs, as originally developed by Bernanke (1983) and more recently by Bloom (2009) and Bloom et al. (2018), and not a consequence of financial frictions. Gilchrist et al. (2014) analyze the relative importance of these two channels. They show that financial frictions are a powerful transmission channel of uncertainty fluctuations to macroeconomic activity through changes in credit spread, corporate debt and leverage ratio of indebted firms-variables who diverged substantially between the Euro area and the US as explained above.

To investigate the role the financial sector plays in business cycles, we specify a DSGE model enriched with financial frictions. The choice of the model in our context is delicate. To make estimation results comparable, the selected DSGE model should be almost identical for each economy, but should also perform well for both economies even though historical data in these economies differ by definition. With this in mind, embedding the model of Bernanke et al. (1999) in an otherwise standard DSGE model as the one of Christiano et al. (2014) (henceafter CMR) has three advantages. First, CMR demonstrate the good empirical performances of this model for accounting US business cycles, especially for recent business cycles up to 2010Q2. It is therefore natural to extend its application to get an insight on the origin of the US recovery. Second, such a model can be viewed as a reduced version of the model developed by Christiano et al. (2010) that has been precisely estimated to compare US and Euro area business cycles. If we abstract from the financial sector, the CMR model is also close to the DSGE model developed by Smets and Wouters (2005) to compare Euro area and US business cycles. ${ }^{7}$ Third, this model pro-

\footnotetext{
${ }^{7}$ They estimate an identical DSGE model with real and nominal rigidities for the US and the Euro area and identify the similarities and the differences in their structural characteristics (e.g. type of shocks,
} 
poses a good compromise between its generality (necessary to be applied identically to the two economies) and its detailed features that allows to account for differences in market frictions (as consumption habit formation, capital adjustment costs, markups, wage/price stickiness, and agency problem in the financial sector), in shocks (associated with shifts in demand, technology, policy or financial risk), and in policies (fiscal or monetary).

We estimate our model for US and Euro area economies over the period 1987Q1-2019Q4. We use quarterly observations of eight macroeconomic series that are standardly used in the estimation of DSGE models as well as four financial series: credit to non financial corporations, slope of the term structure of interest rates, entrepreneurial net worth and credit spread, defined as the difference between credit interest rate and risk-free rate. ${ }^{8}$ This sample of variables is also interesting because other papers based on estimated DSGE models do not provide a comparison between the Euro area and the US that covers the double-dip recession in the Euro area. ${ }^{9}$

We highlight two sets of results. First, we show that an important part of the business cycle variance in output is accounted for by risk shocks in the financial sector in both propagation mechanisms or monetary policy rules). As Smets and Wouters (2005), we do not consider here heterogeneity in Euro area members as well as common shocks between the Euro area and the US. ${ }^{8}$ All these variables, and their role in the estimation, are discussed below.

${ }^{9}$ The most recent papers which estimate DSGE model and focus on US economy do not consider the Euro area and those which focus on Euro area economy do not study the whole double-dip recession. See Galí et al. (2012), Merola (2015), Del Negro et al. (2013), Christiano et al. (2014) or Christiano et al. (2015) for the US economy-Sala et al. (2013) study the US, the UK, Sweden and Germany. For the Euro area economy, the last year of the data sample is 2008 in Darracq Pariès et al. (2011), Christiano et al. (2010) and Villa (2016), 2010 in Coenen et al. (2012) and Lombardo and McAdam (2012) and 2011 in Kollmann et al. (2013). 
economies (41 percent for the US and 44 percent for the Euro area). These shocks are particularly useful to account for episodes of credit crunch, with contraction of both investment and output, and high credit spread. Such a sequence has been observed during the last recessions in US and Euro area economies. According to our estimation results, risk shocks dominate all other shocks in explaining the divergence after the financial crisis between the two economies: a steady reduction of risk supports US credit and investment growth since the trough of 2009 Q2 whereas a substantial increase in risk after the peak of 2011Q2 has plunged the Euro area into a double-dip recession. Such shocks have played a positive role in the Euro area only since 2015 and therefore seem well suited to account for the economic costs of the sovereign debt crisis and the positive effects of unconventional monetary policies, notably the ECB's Asset Purchase Programme (APP). Indeed, the APP was initiated in mid-2014, with monthly asset purchase up to $€ 80$ billion, to supplement Long-Term Refinancing Operations (LTRO) implemented in response to the 2008-2009 recession. This result is robust to various definitions of the series of credit spreads in the Euro area.

Second, even if risk shocks in the financial sector play an important role in business cycles and in the recent divergence between both economies, we highlight significant differences in the propagation of those shocks from the financial sector to the real economy. Indeed, estimated costs to verify the borrower's state turns out to be lower in the Euro area than in the US. Counterfactual experiments show the importance of these structural differences in the divergence between Euro area and US economies.

Both results are important because, while there is a relative consensus on the central role of financial shocks in the US recession of 2008-2009 (Christiano et al., 2014), there is no 
consensus on which shocks are at the origin of $(i)$ the US slow recovery and (ii) the Euro area double-dip recession. Some papers such as Sala et al. (2013) or Galí et al. (2012) do not find that improvements of financial factors support US growth after the through of 2009. They do not, however, consider risk shocks to account for the transmission of financial uncertainty to the real economy, as we do and as suggested by CMR, Arellano et al. (2019) or Gilchrist et al. (2014). Our results show that the US has succeeded in not only reducing but also reversing the risk problem in the economy. On the contrary, the Euro area, hit by a less negative impact of risk than in the US at the beginning of the crisis, has failed to manage this risk as exemplified by the longstanding tensions in its banking sector highly affected by the sovereign debt crisis of $2011 .{ }^{10}$ It is only after 2015 and the asset purchases by the ECB that the effect of risk shocks on GDP became positive. This conclusion is consistent with the DSGE-based assessments of unconventional monetary policy in the Euro area of Cahn et al. (2017) and Mouabbi and Sahuc (2019). It does suggest that, through the risk channel in the financial sector, the APP has been more effective than the LTROs.

The remainder of the paper is organized as follows. Section 2 provides a brief summary of the model and describes the estimation strategy. Section 3 provides our structural interpretation of the divergence. Section 4 discusses our results and their relations to other explanations of the Great recession. Section 5 concludes.

\footnotetext{
${ }^{10}$ Consistently with this result, it is recalled in the introduction of Pisani-Ferry (2014) that in 2009, "everyone was speaking of a global financial crisis" and "if a country could be singled out as being crisis hit, it was the US, where the subprime crisis originated".
} 


\section{Methodology}

We use Dynare (Adjemian et al., 2011) to solve the model and estimate it using observed data for US and Euro area economies. A companion website to this paper is available at https://shiny.cepremap.fr/divergence-website. It provides the main results reported in this paper but can also be used to display supplementary results and robustness checks.

\subsection{The model}

In this section we outline the model first proposed by CMR in order to help readers understand our estimation results. We describe the general equilibrium structure and ize the definition of all shocks that will be introduced.

\subsubsection{The general equilibirum model}

The model belongs to the class of DSGE models with real and nominal rigidities developed by Christiano et al. (2005) and Smets and Wouters $(2003,2007)$ augmented to include financial accelerator mechanism à la Bernanke et al. (1999).

The economy is populated by identical households. Each household contains a unitary continuum of workers and a large number of entrepreneurs. The source of funds for households are labor earnings, bond yields, revenues of capital which is accumulated by households, and other lump-sum transfers. The household allocates funds to consumption purchase, short-term and long-term bonds acquisition, and the purchase of investment goods and existing capital in the economy. The long-term bond interest rate is determined in the model by the expectations for the short-term rate. A shock is included in the longterm bond interest rate to match the term premium in the data. This shock is referred 
as the term structure shock. The representative household maximizes the expected value of the discounted utility of its members derived from leisure time and from consumption with habit formation. Preference shocks affect the household utility function. This shock is referred as the consumption preference shock.

The final good is produced from a continuum of intermediate goods using a Dixit-Stiglitz technology. The elasticity of substitution among intermediate goods is stochastic to account for markup fluctuations. This shock is referred as the price markup shock. The producers of intermediate goods use the services of physical capital and labor, following a stochastic Cobb-Douglas production function subject to transitory shocks on the total factor productivity and growth shocks on the trend of labor technological progress. These shocks are referred as the temporary technology shock and the persistent technology growth shock, respectively. The second source of growth of the model is an investment specific technology growth, which decreases the price of investment. It is also submitted to a shock referred as the investment price shock.

Prices and wages are subject to nominal rigidities à la Calvo. Monopoly suppliers of labor and of intermediate goods can reoptimize their wage and price only periodically (with an exogenous probability), otherwise they follow an indexation rule that depends on the target inflation rate fixed by the monetary authority. This target is submitted to the inflation target shock. In addition to targeting inflation, the monetary authority sets the nominal interest rate given its past value, the deviations of inflation and output with respect to their steady-state values, and a stochastic disturbance, which is referred as the monetary policy shock. A second policy shock is introduced through the government consumption of final good, which is affected by a stochastic disturbance referred as the government 
consumption shock.

Households accumulate raw capital by purchasing the existing undepreciated capital of the economy and investment goods, which are subject to adjustment costs. Adjustment costs are stochastic because of a shock on the marginal efficiency of investment in producing capital, which is referred as the marginal efficiency of investment shock. Raw capital cannot be directly used in the production sector that uses effective capital. Households sell raw physical capital to entrepreneurs who transform it into effective capital. To buy raw capital, entrepreneurs use their personal wealth and a loan obtained from a financial intermediary. The loan contract is characterized by agency problems subject to financial shocks. Given the importance of financial shocks for our analysis, we provide a more detailed description of these shocks below.

\subsubsection{The financial shocks}

The agency problem is associated with the asymmetric information between the entrepreneur and the financial intermediary that makes costly checking the state of defaulting entrepreneur-hence the expression costly-state verification proposed by Townsend (1979).

Let $N$ be the personal wealth of the entrepreneur and $B$ the size of the loan. ${ }^{11}$ The purchase of $K$ units of raw capital at price $Q_{K}$ satisfies $Q_{K} K=N+B$. The $K$ units of raw capital are transformed into $\omega K$ units of effective capital that will be sold to the final good producers. $\omega$ is the idiosyncratic shock that makes the business of entrepreneurs risky. The idiosyncratic shock has a unit-mean log normal distribution denoted $F(\omega)$. It is observed by the entrepreneur after her purchases of raw capital. If the realized value is

\footnotetext{
${ }^{11}$ To simplify the presentation we omit the time index.
} 
too low, namely $\omega<\bar{\omega}$, the entrepreneur defaults because it cannot reimburse the loan.

The equilibrium value of $\bar{\omega}$ satisfies

$$
R^{k} \bar{\omega} Q_{K} K=B Z
$$

where $R^{k}$ is the return on effective capital and $Z$ the loan interest rate. The return on revenues received by the financial intermediary from its entrepreneur is

$$
[1-F(\bar{\omega})] Z B+(1-\mu) \int_{0}^{\bar{\omega}} \omega d F(\omega) R^{k} Q_{K} K
$$

With the probability of no-default $[1-F(\bar{\omega})]$, the financial intermediary receives interest on its loan. Otherwise, the financial intermediary gets the share $1-\mu<1$ of the assets of the bankrupt entrepreneur (the collateral) where $\mu$ measures the size of the state verification costs.

The standard deviation of the idiosyncratic shocks $\omega$ is modified by what we call the risk shock in the following way. Denoting by $\sigma_{t}$ the standard deviation of $\log (\omega)$, it evolves as follow in the following fashion:

$$
\log \left(\sigma_{t} / \sigma\right)=\rho_{\sigma} \log \left(\sigma_{t-1} / \sigma\right)+u_{t}
$$

where $u_{t}$ is an iid innovation to the risk in the economy, $\rho_{\sigma}$ is the persistence of the risk shock, and $\sigma$ the steady-state level of risk. An increase in $\sigma_{t}$ makes higher the cross-sectional dispersion in $\omega$. Because the mean of $\omega$ is unchanged, it means higher probabilities for low realizations of $\omega$ and therefore higher default risk in the economy.

The second financial shock modifies the net wealth of entrepreneurs. With a stochastic probability, the household takes all the wealth of the entrepreneur. The entrepreneur can however still get a loan thanks to an exogenous transfer from the households, but 
the agency problems are reinforced because the value of its assets (or the collateral) is reduced. This shock is referred as the equity shock.

Finally, we consider news on the risk shock that evolves as follows

$$
u_{t}=\xi_{0, t}+\xi_{1, t-1}+\ldots+\xi_{p, t-p}
$$

where $\xi_{0, t}$ is the unanticipated component of $u_{t}$ and $\xi_{j, t-j}$ for $j>0$ is the anticipated (or news) components of $u_{t}$. These shocks are referred to news shocks.

\subsection{Inference about parameters}

\subsubsection{Presentation of the data}

We use quarterly observations on twelve variables covering the period 1987Q1-2019Q4 for the Euro area and for the US. These include eight variables that are standard in bayesian estimation of DSGE models: GDP, consumption, investment, inflation, wage, price of investment, hours worked and short-term risk-free interest rate. As CMR, we also use four financial variables: credit, slope of the term structure of interest rates, entrepreneurial net worth and credit spread.

For Euro area, we use the Area-wide Model (AWM) database (Fagan et al., 2001), up to 1999 Q1. ${ }^{12}$ We then link, where it is feasible, the data contained in the orginal AWM database to the official Euro area data. This is legitimate because the AWM database has been constructed using both Euro area data reported in the ECB Monthly Bulletin and other ECB and Eurostat data where available. ${ }^{13}$.

\footnotetext{
${ }^{12}$ We use the 15 th update of the AWM database.

${ }^{13}$ Details and code to reproduce the database are available in the following links: https://macro.cepremap.fr/article/2015-10/sw03-data/, https://macro.cepremap.fr/article/2016-
} 
Credit spread is a key variable in the estimation of a model with financial frictions. So our choice of a different definition from CMR in the European case has to be explained. Corporate bond spread appears to be a good proxy of credit spread in places like the US where lending is mostly done by financial markets. When the financial system is dominated by banks, as is the case in the Euro area, it is more appropriate to choose an average of the retail bank interest rates, that we choose here. ${ }^{14}$ To assess the robustness of our results to this choice, we also estimate the model using the average yield of Euro area private sector bonds series constructed by Gilchrist and Mojon (2018) instead of the retail bank interest rate.

\subsubsection{Calibration}

Table 1 contains a description of the parameters that we fix during the estimation. We comment here only on calibrated parameters which differ between the Euro area and the US. ${ }^{15}$ We set the growth rate $\mu_{z}$ of the unit root technology shock and the growth rate of investment-specific technological change $\Upsilon$ to 1.66 percent and 1.70 percent respectively for the US, and to 2.00 percent and 0.38 percent respectively for the Euro area. The short-term risk-free rate and the inflation target are fixed at $5.86 \%$ and $2.77 \%$ respectively in annual percent rate for the Euro area and $4.67 \%$ and $2.43 \%$ for the US. The discount rates are deduced to allow equality of Euler equation at the steady state. $\eta^{g}$ is fixed to obtain an appropriate government consumption ratio to GDP. For Euro area data, tax

06/cmr14-EA-data/ and https://macro.cepremap.fr/article/2016-06/cmr14-data/.

${ }^{14}$ See De Fiore and Uhlig (2011), Reichlin (2014) and Grjebine et al. (2018) for evidence on the differences between the two financial system.

${ }^{15}$ The following numbers correspond to the mean of each variable during the period of the Great moderation. 
rates are sample means of implicit tax rates (1995-2008). ${ }^{16}$ When we compute the share of capital in total income in the Euro area, we obtain 0.4 , a very similar figure than in the US.

\section{Table 1 - Calibrated parameters}

\begin{tabular}{|c|c|c|c|}
\hline & & EA & US \\
\hline$\beta$ & Discount rate & 0.9998 & 0.9987 \\
\hline$\psi_{L}$ & Disutility weight on labor & 0.7705 & 0.7705 \\
\hline$\delta$ & Deprecation rate of the economy & 0.025 & 0.025 \\
\hline$\alpha$ & Power on capital in production function & 0.40 & 0.40 \\
\hline$\sigma_{L}$ & Curvature on disutility of labor & 1 & 1 \\
\hline$\Upsilon$ & Growth rate of investment specific technological change (APR) & 0.38 & 1.70 \\
\hline$\mu_{z}$ & Growth rate of the economy (APR) & 2.00 & 1.66 \\
\hline$\lambda_{w}$ & Steady state markup, suppliers of labor & 1.05 & 1.05 \\
\hline$\lambda_{f}$ & Steady state markup, intermediate good firms & 1.20 & 1.20 \\
\hline $1-\gamma$ & Fraction of entrepreneurial net worth transferred to households & $1-98.50$ & $1-98.50$ \\
\hline$W^{e}$ & Transfer received by new entrepreneurs & 0.005 & 0.005 \\
\hline$\Theta$ & Share of resources for state verification & 0.005 & 0.005 \\
\hline$\eta_{g}$ & Steady state government consumption-GDP ratio & 0.198 & 0.204 \\
\hline$\pi^{\text {target }}$ & Steady state inflation rate (APR) & 2.77 & 2.43 \\
\hline$R$ & Short-term risk-free interest rate (APR) & 5.86 & 4.67 \\
\hline$\tau^{c}$ & Tax rate on consumption & 0.191 & 0.047 \\
\hline$\tau^{k}$ & Tax rate on capital income & 0.386 & 0.320 \\
\hline$\tau^{\prime}$ & Tax rate on labor income & 0.374 & 0.241 \\
\hline
\end{tabular}

${ }^{16}$ Details and code to reproduce the calibration of the tax rates can be found https://macro.cepremap.fr/article/2019-11/implicit_tax_rates/. 


\subsubsection{Estimation}

The model is estimated through Bayesian procedures surveyed by An and Schorfeide (2007). Prior and posterior of estimated structural parameters and shock processes, which are the same for both countries, are detailed in Table .1 in Appendix.

For the US economy, results can be compared with those reported by CMR to assess how estimation results are sensitive to the selected period. The single difference for the US economy is that our sample period is 1987Q1-2019Q4 against 1985Q1-2010Q2 in CMR. ${ }^{17}$ Our posterior modes are very close to that of CMR. We therefore focus our analysis on the differences between the Euro area and the US-see Table.1. We compare the 80 percent confidence intervals to identify some structural differences between the two economies. One parameter value is considered as significantly different when its posterior mode for one economy does not fall within the confidence interval of the other economy.

We observe significant differences in the degree of real frictions. The degree of habit formation is lower in the Euro area than in the US while the curvatures of the investmentcost and utilization-cost technologies turn out to be higher in the US than in the Euro area.

Our estimation results also indicate significant differences in the degree of nominal rigidities both for prices and wages. Wages are more sticky in the Euro area than in the US whereas it is the opposite for price stickiness. ${ }^{18}$ In Christiano et al. (2010) the Calvo parameters are

\footnotetext{
${ }^{17}$ We restrict the beginning of the US data sample to have the same time span in both economies.

${ }^{18}$ For the posterior distributions, wages are not revised with a probability equal to 0.77 in the Euro area whereas it is 0.71 in the US. For prices, the probability of no-revision is 0.79 in the US against 0.59 in the Euro area.
} 
very close for the two markets and for the two economies without significant differences. ${ }^{19}$ In Smets and Wouters (2005), there is no significant difference for price rigidities but the Calvo parameter for wage stickiness is significantly higher in the US than in the Euro area. This difference vanishes, however, when they restrict the data sample to the period after 1983. Substantial differences also concern the indexing of prices and wages in the case of no-revision.

Another striking difference between the two economies lies in financial frictions. Monitoring costs, namely $\mu$, are estimated to represent $8.6 \%$ of seized assets in the Euro area (the $80 \%$ confidence interval is [4.1-14.7]) against $26.8 \%$ in the US (the $80 \%$ confidence interval is [15.1-38.1]). Consistently, given a lower verification cost of default in the Euro area, the probability of default and the leverage ratio of non-financial corporations are higher in this economy when compared with the US. ${ }^{20}$

The conclusion that financial frictions are less severe in the Euro area than in the US deserves some discussion. First, it is worth mentioning that the degree of financial frictions is rarely estimated in comparable DSGE models for Euro area and US economies. Indeed, the seminal contributions of Smets and Wouters $(2003,2005,2007)$ do not consider financial frictions while the degree of monitoring costs is calibrated and not estimated by Christiano et al. $(2008,2010)$. The interest of the contributions of von Heideken (2009) and Villa (2016) is precisely to provide comparable estimates of the degree of financial frictions which is higher in the Euro area than in the US according to these authors. However, it is worth mentioning that in both papers the differences between the

\footnotetext{
${ }^{19}$ The lowest probability of no-revision is 0.693 for prices in the US and the highest is 0.712 for wages in the E-see Table 4 in Christiano et al. (2010).

${ }^{20}$ The default probability is $0.7 \%$ for the Euro area against $0.5 \%$ for the US.
} 
two modes of the structural parameters are not statistically different-that is the mode of the parameter estimated for one economy falls in the confidence interval estimated for the other economy. This is not the case in this paper since the two confidence intervals for $\mu$ for the two economies do not overlap as explained above. The differences between our results and that of von Heideken (2009) and Villa (2016) can be explained by the fact that we consider a set of financial series to estimate the DSGE models-Christiano et al. (2014) emphasize the importance of using financial series to estimate DSGE models with financial frictions. We are therefore the first to exhibit significant structural differences between the European and American financial systems in the business cycle literature based on estimated DSGE models.

Second, it should be emphasized that the choice of the financial series to estimate the model takes into account the differences between the two financial system. For the US, the series of credit spread is calculated for market debt and the series of credit includes all credit instruments in which market debt is the most important component. For the Euro area, the credit spread and the amount of credit are both defined for bank loans, which is the main source of credit to non financial corporations in this economy. The lack of market debt in the Euro area can be viewed as a the consequence of other financial frictions than the costly-state verification considered herein, which are not present in our model. For example, De Fiore and Uhlig $(2011,2015)$ suggest that the availability of public information about firms' credit worthiness and the efficiency of banks in acquiring this information can explain the observed gap between the two economies. Because our analysis assumes a single financial market it cannot explain the causes of the orientation toward bank- or market-based debt for non financial corporations, but it can highlight 
differences in the financial accelerator mechanism between a bank-based economy (the Euro area) and a market-based economy (the US economy).

Third, our results are consistent with microeconomic evidence on the size of monitoring costs. Carlstrom and Fuerst (1997) were among the first to quantify the value of $\mu$ in business cycle models and find it to be in the range of [0.20-0.36]. This quantification is based on various evidence on the bankruptcy costs in the US economy. This literature also shows substantial differences on the recovery rates for lenders according to the nature of the debt contract. Indeed, according to Cantor and Varma (2005) and Khieu et al. (2012), bank loans are generally more secured than bonds and then give rise to a higher recovery rate in the case of default which corresponds to $(1-\mu)$ in the model. The low value of $\mu$ estimated for the Euro area is finally not so surprising since we consider bank loans for this economy and not bond debt as done for the US economy. Consistent with this interpretation, we find substantially higher monitoring costs in the Euro area when the model is estimated using the series of credit spreads constructed by Gilchrist and Mojon (2018), based on Euro area private sector bonds, instead of retail bank interest rate - the estimated value of $\mu$ reported in Table .2 is twice as high, equal to $17.2 \%$ against $8.6 \%$ in Table .1.

One important consequence of the difference in the estimated parameters of the financial contract is the difference in the propagation of risk shocks from the financial sector to the real economy. To understand that, we must explain the link between the degree of financial frictions and the sensitivity of macroeconomic variables to risk shocks. Consider the credit spread as the premium asked by lenders given the risk of default. Risk fluctuations imply negative co-movements between credit spread and the growth rate of credit: when risk 
is higher, lenders lend less and ask for a greater premium. The credit crunch is then transmitted to macroeconomic activity through physical capital market and investment decisions as illustrated by Figure 2, which shows the impulse response functions of main variables to an unanticipated innovation in the risk shock. Other things being equal, stronger financial frictions in the US amplify the responses of macroeconomic variables to risk shocks.

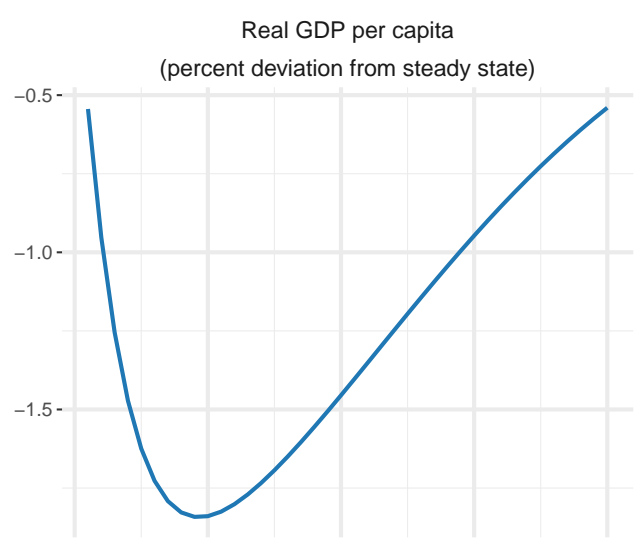

Real credit per capita (percent deviation from steady state)

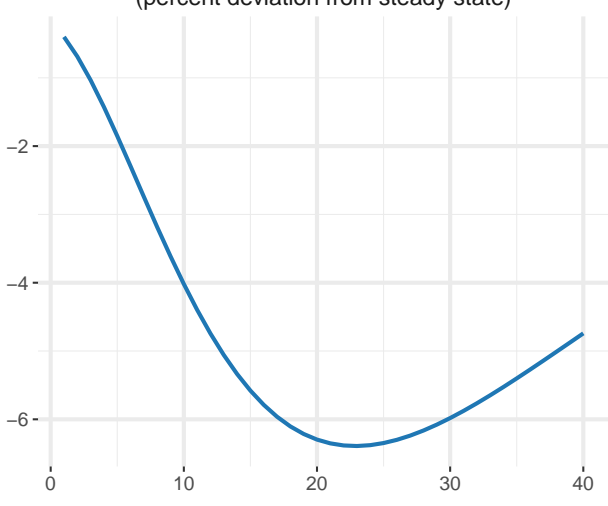

Real investment per capita

(percent deviation from steady state)

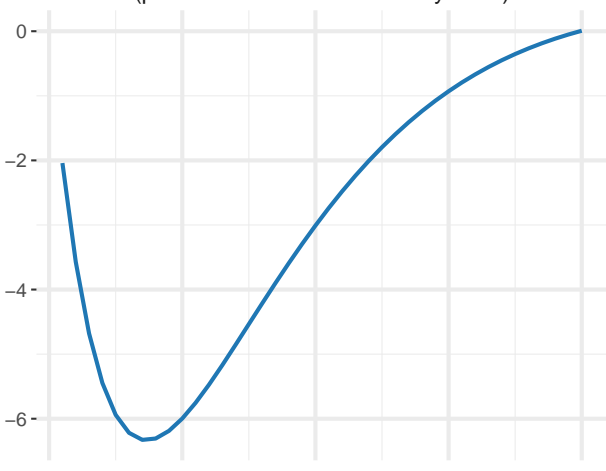

Credit spread

(annual basis point)

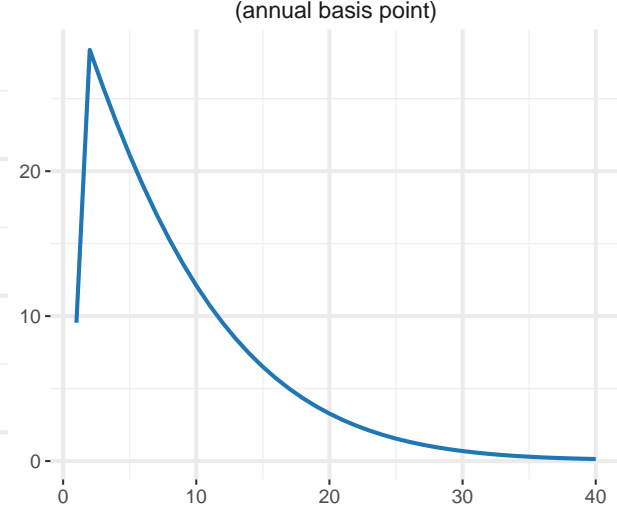

Figure 2 - Dynamic responses after increasing an unanticipated risk shock in the United

\section{States}




\section{Explaining the divergence}

\subsection{The role of risk shocks in the divergence}

The fluctuation of risk shocks is historically an important source of business cycles for both economies as shown in Figure 3 and Table 2. This result is consistent with Christiano et al. $(2010,2014)$. The risk shock accounts for around half of the business cycle variance in output in both economies (44 percent for the Euro area, 41 for the US) and more than two-thirds of the variance in investment (68 percent for the Euro area and 66 percent for the US). ${ }^{21}$

The role of risk shocks is central in explaining the divergence between Euro area and US economies during the last recessions. Figure 4 compares actual real GDP per capita with its simulated values, feeding only risk shocks to the model, since 2007Q4. ${ }^{22}$ In the US, risk shocks have negatively contributed to growth between 2008Q3 and 2010Q1, with a trough in 2009Q2. After this period, we observe a reversal in risk shocks that contribute positively to the US output growth. In fact, the US recovery would have been weaker without this reversal in risk shocks.

\footnotetext{
${ }^{21}$ Darracq Pariès et al. (2011) also conclude that roughly 50 percent of the unconditional variance of real macroeconomic variables are explained by financial and housing-specific shocks. Some other contributions, however, find that financial shocks only explain in a minor way the volatility of real macroeconomic variables in Europe as Quint and Rabanal (2014). The differences come from the definition of financial shocks. In Quint and Rabanal (2014) the financial accelerator mechanism is placed on the household side and the risk shocks concern the quality of housing stock.

${ }^{22}$ Another way to look at Figure 4 is that the solid lines correspond to simulated values feeding all the shocks to the model (approximately because of some measurement errors).
} 
Table 2 - Variance decomposition at business cycle frequency (Percent)

risk equity investment technology markup cons. pref. mon. pol. gov. cons.

\section{Euro Area}

\begin{tabular}{|c|c|c|c|c|c|c|c|c|}
\hline GDP & 44.28 & 4.42 & 4.99 & 8.14 & 11.01 & 3.56 & 6.78 & 16.75 \\
\hline consumption & 15.85 & 1.53 & 9.11 & 10.67 & 11.60 & 45.93 & 2.66 & 2.61 \\
\hline investment & 67.51 & 7.26 & 11.75 & 2.30 & 4.80 & 1.54 & 4.68 & 0.11 \\
\hline credit & 15.67 & 76.02 & 3.59 & 1.72 & 1.45 & 0.39 & 0.91 & 0.27 \\
\hline net worth & 22.54 & 22.81 & 50.05 & 0.06 & 0.11 & 0.00 & 4.37 & 0.04 \\
\hline invest. price & 0.00 & 0.00 & 100.00 & 0.00 & 0.00 & 0.00 & 0.00 & 0.00 \\
\hline wage & 15.16 & 0.91 & 3.42 & 60.76 & 16.55 & 0.39 & 1.55 & 1.25 \\
\hline inflation & 55.49 & 3.37 & 9.46 & 11.76 & 10.95 & 1.80 & 5.54 & 1.50 \\
\hline hours worked & 54.45 & 3.15 & 9.32 & 4.38 & 16.40 & 2.43 & 5.57 & 4.26 \\
\hline interest rate & 75.89 & 4.44 & 10.16 & 2.18 & 1.55 & 1.27 & 3.92 & 0.52 \\
\hline credit spread & 78.84 & 7.97 & 11.92 & 0.04 & 0.03 & 0.02 & 1.18 & 0.02 \\
\hline term structure & 73.23 & 3.36 & 6.39 & 1.21 & 1.42 & 0.37 & 4.57 & 0.22 \\
\hline \multicolumn{9}{|l|}{ United States } \\
\hline GDP & 40.90 & 0.36 & 14.85 & 13.87 & 7.60 & 5.33 & 1.99 & 15.08 \\
\hline consumption & 4.43 & 0.03 & 3.91 & 22.60 & 10.69 & 54.82 & 2.10 & 1.40 \\
\hline investment & 66.12 & 0.60 & 26.67 & 1.38 & 3.61 & 0.46 & 1.15 & 0.00 \\
\hline credit & 39.25 & 37.06 & 10.87 & 3.78 & 6.75 & 1.39 & 0.65 & 0.25 \\
\hline net worth & 68.12 & 2.81 & 24.87 & 0.26 & 0.90 & 0.02 & 2.97 & 0.04 \\
\hline invest. price & 0.00 & 0.00 & 100.00 & 0.00 & 0.00 & 0.00 & 0.00 & 0.00 \\
\hline wage & 0.68 & 0.00 & 0.35 & 90.91 & 7.97 & 0.02 & 0.01 & 0.05 \\
\hline inflation & 30.50 & 0.20 & 13.84 & 12.46 & 35.94 & 4.72 & 1.61 & 0.60 \\
\hline hours worked & 43.73 & 0.28 & 21.68 & 12.17 & 11.97 & 4.44 & 1.90 & 3.82 \\
\hline interest rate & 46.69 & 0.32 & 19.16 & 6.06 & 13.69 & 5.57 & 8.00 & 0.49 \\
\hline credit spread & 94.89 & 1.02 & 3.36 & 0.08 & 0.11 & 0.04 & 0.48 & 0.01 \\
\hline term structure & 45.48 & 0.29 & 16.05 & 2.91 & 11.08 & 3.15 & 8.32 & 0.20 \\
\hline
\end{tabular}

Note: For each observed variable in row, the "risk" column is the sum of the variance explained by anticipated and unanticipated components of the risk shocks, the "investment" column is the sum of the variance explained by investment price and investment efficiency shocks and the "technology" column is the sum 

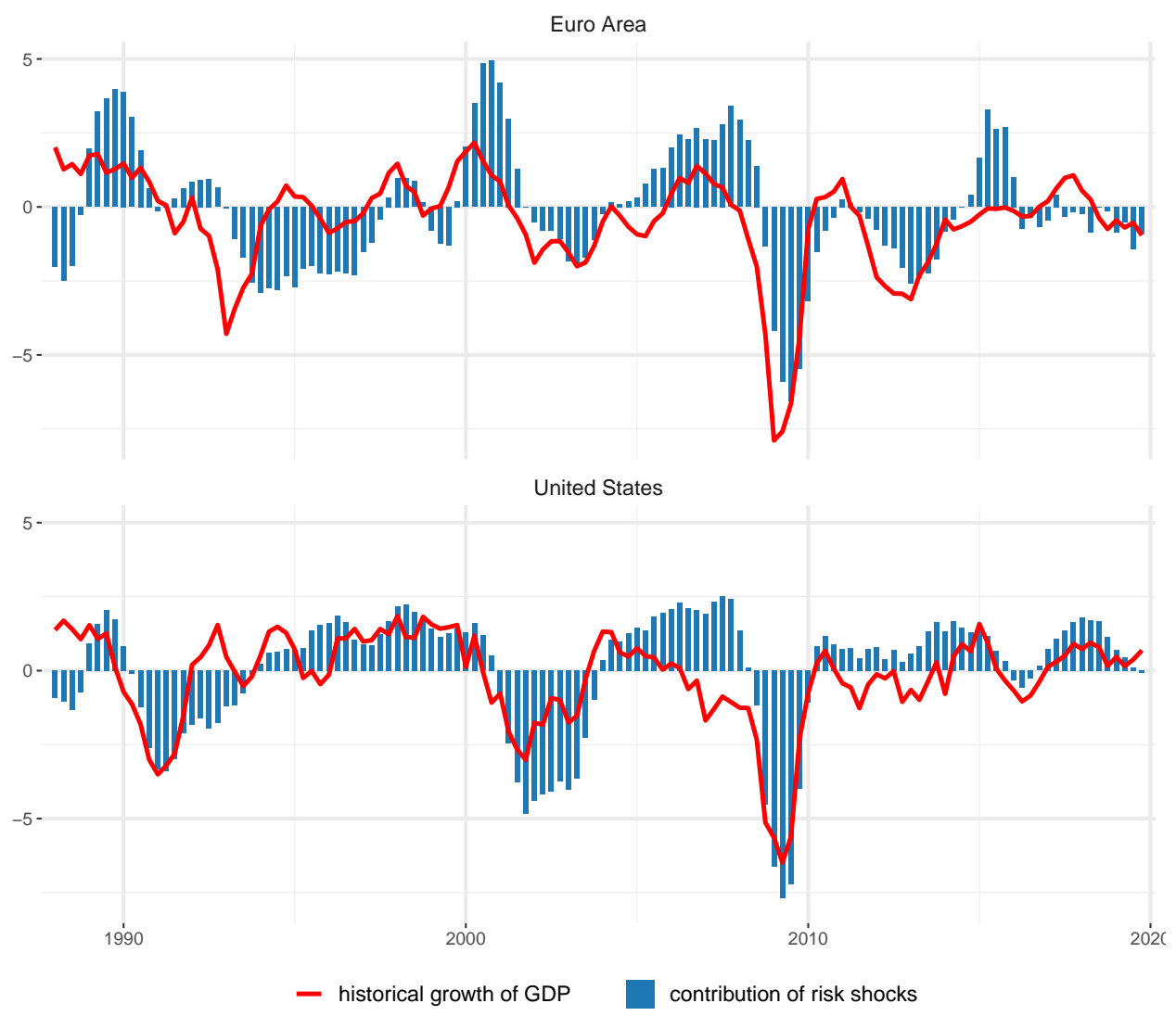

Figure 3 - Historical contribution of risk shocks to the growth rate of real GDP per capita, year-on-year (1988Q1-2019Q4)

Note: The solid line is the historical growth of real GDP per capita (year-on-year). The "contribution of risk shocks" is the sum of the contributions to GDP fluctuations explained by anticipated and unanticipated components of the risk shocks.

The contribution of risk shocks to growth has been different in the Euro area. First, the deterioration of risk in the financial sector comes later with lesser impact on growth during the first recession than in the US. Indeed, the first recession in the Euro area started in 2008Q1 but the negative contributions of risk shocks to growth started in 2008Q4. However, the key difference between the two economies is the absence of risk reversal in the Euro area. It is even worse for the Euro area because the negative contribution of risk increases after 2011Q1 giving rise to the double-dip recession. 


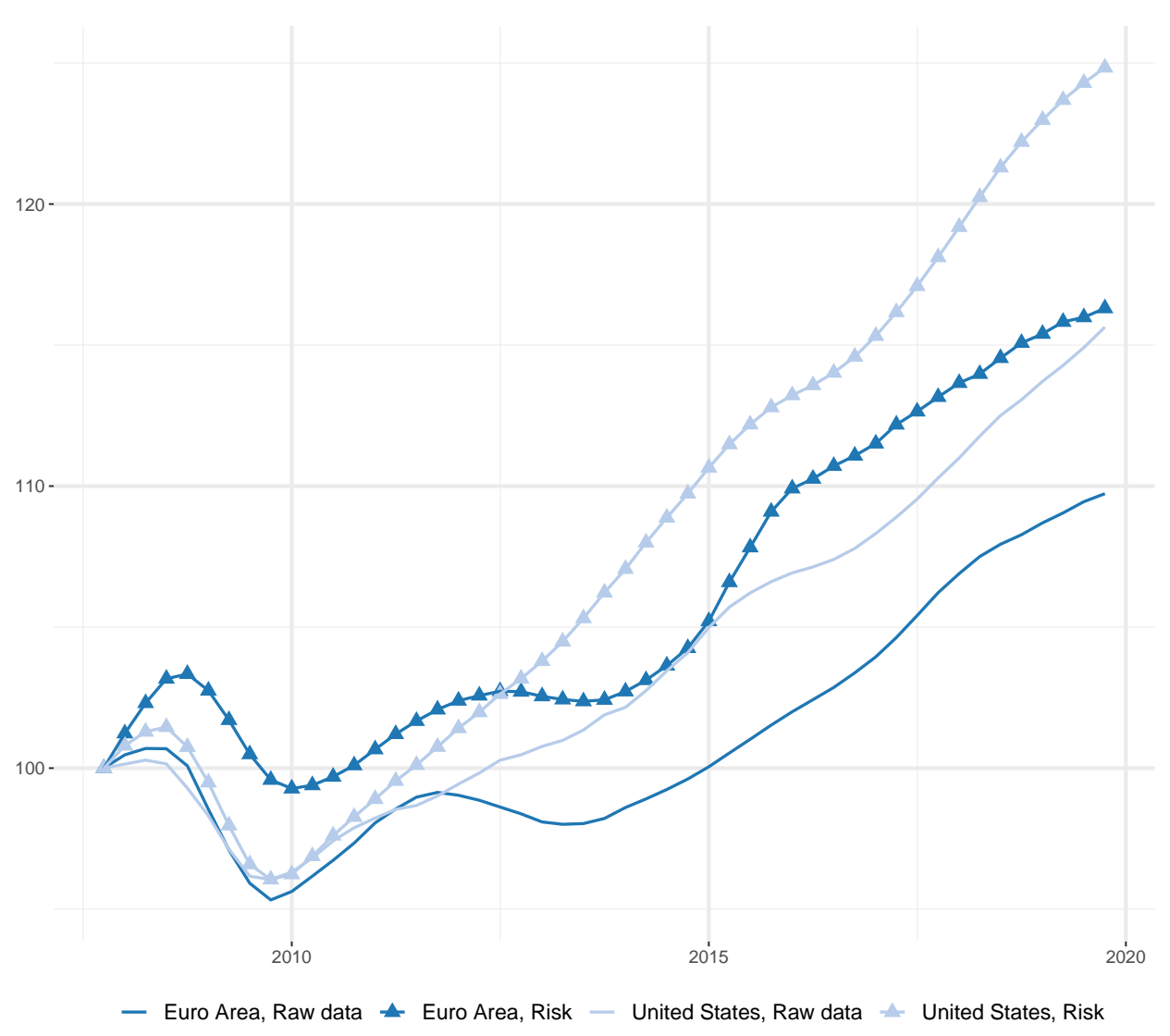

Figure 4 - Historical and simulated real GDP per capita in the US and the Euro area in level (base $100=2007 Q 4)$

Note: The solid lines are the historical data and the starred lines are the simulated data, in which only the anticipated and unanticipated components of the risk shock are fed to the model.

Figure 5 provides a detailed view of the role of risk shocks during the Great recession for four key variables: GDP, investment, credit and credit spread. Consistently with the previous analysis of the IRFs, since 2007 risk fluctuations are at the origin of the sharp rise and fall in the US credit spread associated with the credit crunch, followed by a rapid credit growth that drives the growth of investment and output. For the Euro area, we do not observe a substantial fall of the credit spread after the first recession of 2008-2009, it even starts to increase again in 2011. Consequently, credit growth has continued to fall and the growth rates of investment and output are below their steady-state values until 
2015.
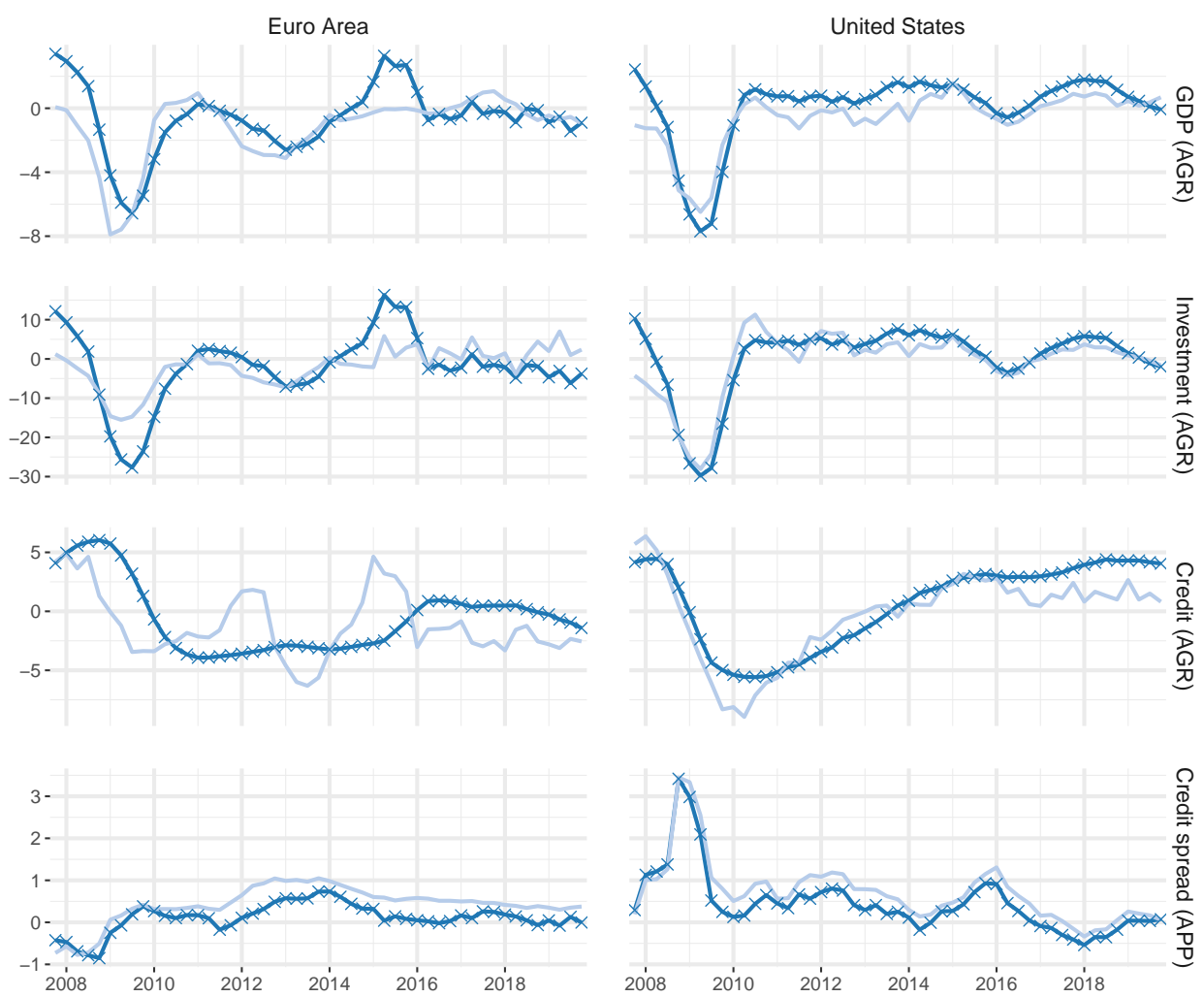

- Raw data * Risk

Figure 5 - The role of the risk shock in observed variables in the Euro area and the US (2007Q4-2019Q4)

Note: Solid lines correspond to the annual growth rates (AGR) of real GDP, investment and credit per capita and annual percentage point (APP) of credit spread, without mean. Starred lines are the simulated data, in which only the anticipated and unanticipated components of the risk shock are fed to the model.

Cumulated growth from 2007Q4 to 2019Q4 is 5.9 percentage points higher in the US than in the Euro area, whereas it would have been 8.5 percentage points higher if only risk shocks had occurred in these economies. It means that other shocks have increased growth in the Euro area and decreased it in the US in a way that dampens the divergence between the two economies. 


\subsection{The role of other shocks and structure}

Risk shocks are not the only reason for the 2008-2009 Euro area recession. Another reason is a sequence of negative temporary productivity shocks between 2008Q2 and 2010Q2. Risk shocks are by far the most important negative source of growth during the second recession. ${ }^{23}$ Other sources of shocks have helped mitigate the effects of the rising risks since 2007: an accommodative monetary policy, a temporary fall in price mark-up, and an improvement in marginal efficiency of investment.

As in the Euro area case, risk shocks are not the sole reason of the first recession in the US. In the US, the second reason for negative growth by order of importance is the price markup shock. The rise of risk and of price markup are mitigated by a positive temporary productivity shocks (contrary to the Euro area) and positive government consumption shocks (the last turned negative after the recession).

The Euro area and the US can also differ by their structures, not only by the various shocks that hit their economies. In Section 2, we highlight important differences between the financial structures of the two economies: the cost of state verification is lower in the Euro area than in the US. To assess the role of the financial structure in the divergence between Euro area and US economies, we perform a counterfactual analysis that imposes the estimated risk shocks of the Euro area economy in the US economic structure. Reciprocally, the estimated risk shocks of the US economy are imposed in the Euro area economic structure. Results are depicted in Figure 6.

${ }^{23}$ See the companion website for the historical decomposition of all shocks: https://shiny.cepremap.fr/divergence-website. 


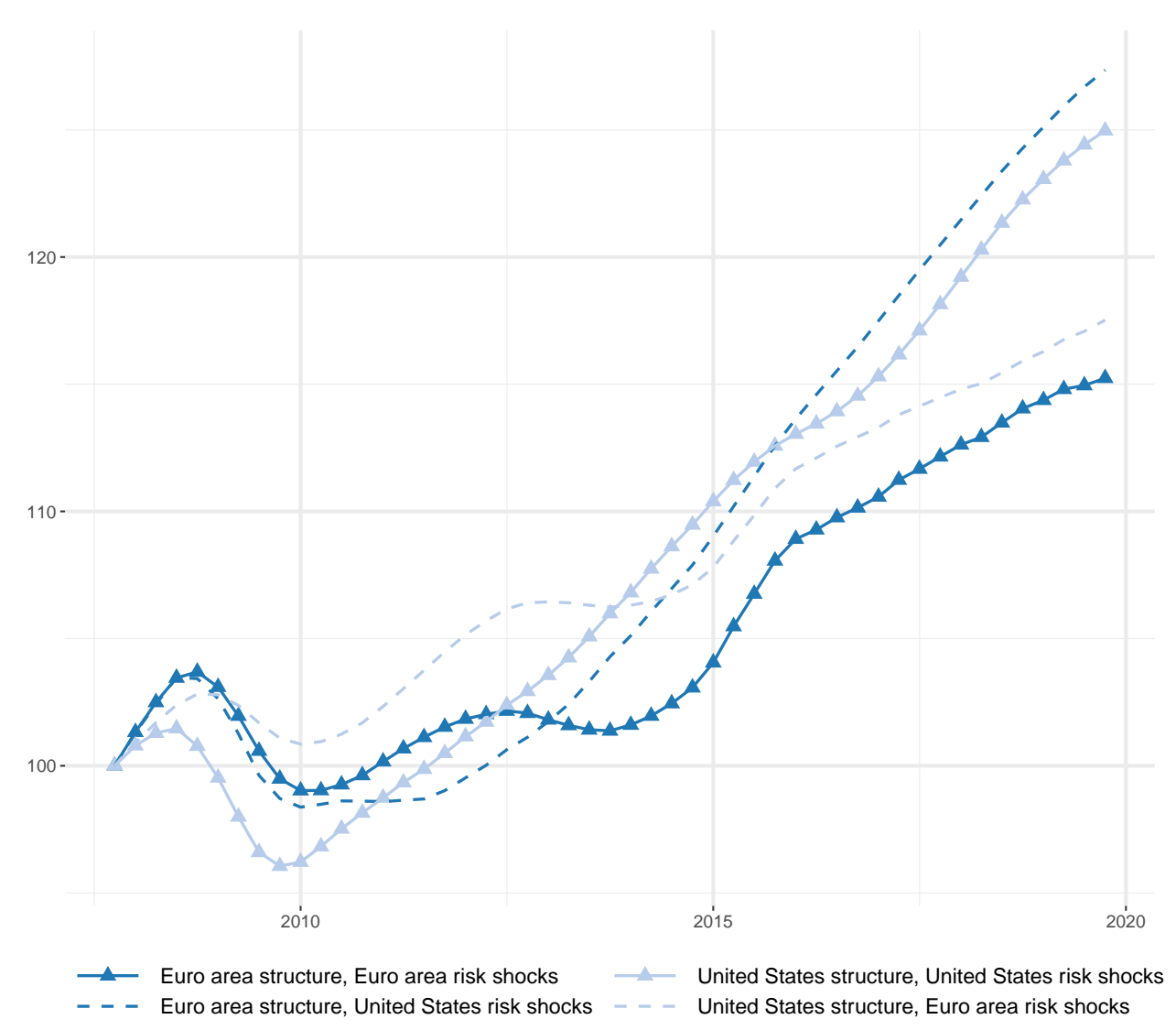

Figure 6 - Euro area and US specific economic structures hit by Euro area and US risk shocks

Note: The starred lines are the simulated data, in which only the anticipated and unanticipated components of the risk shock are fed to the model. The dashed lines are counterfactual simulated data.

It appears that the US economy would also have experienced a double-dip recession assuming the Euro area sequence of shocks and the US economic structure. Importantly, given the size of the financial frictions in the US, the second recession would have been even longer than in the Euro area. Conversely, no double-dip recession would have occurred in the Euro area if this economy had experienced the US shocks and the 2008-2009 recession would have been less severe than observed in the US. 


\section{Relation to other narratives of the Great recession}

Why did the Euro area economy fall a second time into recession in 2011 while the US economy did not? According to our estimation results, risk shocks are central to explaining the divergence because they are at the origin of both the US recovery and the Euro area double-dip recession. This section compares this interpretation with alternative explanations of these recent recessions.

\subsection{What drives the US slow recovery?}

Our analysis for the US economy is close to the analysis of CMR by construction. Our contribution is to extend the data sample up to 2019Q4 (the sample of CMR stopped in 2010Q2). CMR demonstrated that risk shocks account for the same magnitude of the GDP variations between 2008 and 2010. Our results complement this analysis by demonstrating the positive role of risk shocks after 2010. Indeed, after the financial crisis of 2007-2009, the amount of risk in the US economy not only returns to its normal level, but it goes below in such a way that it is the main source of growth of the current expansion. It is worth emphasizing that this interpretation of the recent US experience is still under debate. While there is a consensus on the role of financial shocks in the contraction/recovery of 2008-2010, this is not the case for the period after 2010.

In Del Negro et al. (2013), risk shocks increase output growth during three quarters in 2009 and then decrease it. Sala et al. (2013) and Galí et al. (2012) estimate DSGE models with equity premium shocks as financial shocks (but no risk shocks) and conclude that the contribution of financial shocks to GDP is always negative between 2008 and 2011. To explain our results on the positive role of risk shocks, it is important to notice 
that, contrary to Sala et al. (2013) and Galí et al. (2012), we consider risk shocks as financial shocks, and not only equity premium shocks as they do. Furthermore, contrary to Del Negro et al. (2013) who use only the credit spread, we also use, as suggested by CMR, the volume of credit to non-financial corporations series to estimate the model. In fact, the credit spread returned to its average value or slightly above after 2010Q1 while credit growth is clearly above its average value during the 2012-2013 years, a situation that can be explained by a decrease of risk in the financial sector in our model.

This outcome of our estimation procedure is consistent with the analysis of the US credit market provided in the Global Financial Stability Report (IMF, 2013a). Credit growth is qualified as weak in most advanced countries except for the non-financial corporations in the US economy. The very low market interest rates are pointed out as the potential source of this credit expansion and Stein (2013) and Rajan (2013) warn about the risk of this credit expansion for financial stability. They suggest that this credit expansion may be the outcome of an excessive risk taking behavior similar to that observed before the 2008-2009 recession. According to our estimation results, the positive contribution of risk shocks in US growth is effectively close to that observed during the years before the crisis-see Figure 3.

\subsection{Is the Euro area double-dip recession due to financial factors?}

The first Euro area recession of 2009 can be interpreted as a financial recession given the important contributions of risk shocks even if they do not account for the full magnitude as for the US case. This result is consistent with the earlier finding of Christiano et al. (2010) who compare the role of financial frictions in Euro area and US business cycles up 
to 2008Q2. In a similar vein, Gerali et al. (2010) and Kollmann et al. (2013) attribute the output contraction of 2008-2009 to shocks originating in the banking sector. ${ }^{24}$ Less evidence is provided in the literature to the second recession of 2011 , which is one of our contributions to this literature. Sala et al. (2013) and Kollmann et al. (2016) are two exceptions. Sala et al. (2013) reports a weak role for financial shocks in the business cycles of three European countries (namely the UK, Sweden, and Germany) during the period 2007-2011. ${ }^{25}$ They do not consider risk shocks as financial shocks but only equity premium shocks. In addition, countries they have selected do not experienced a doubledip recession as observed by us for the Euro area and by Reinhart and Rogoff (2014) for the following members of the Euro area: France, Ireland, Italy, Netherlands and Portugal. Kollmann et al. (2016) consider the Euro area as a whole in a three-region DSGE model. They conclude as we do show that financial shocks were key drivers of the 2008-09 Great Recession, both in the Euro area and the US. When it comes to the post-2009 period, they attribute the slump in the Euro area mainly to a combination of adverse aggregate demand and supply shocks, in particular lower productivity growth.

Our contribution is therefore to provide a DSGE-based structural interpretation of the 2011 recession in the Euro area and to attribute it to an increase of the risk in the financial sector. Since 2011, the Euro area has been marked by sovereign debt crisis in Greece, Portugal, Ireland, Spain, and Cyprus. Because of the "doom loop" between the sovereign and bank debts, the sovereign debt crisis has been a major source of tensions in

\footnotetext{
${ }^{24}$ In Lombardo and McAdam (2012), financial shocks contribute strongly to the fluctuations of house prices and to a lesser extent to those of output between 2008 and 2010.

${ }^{25}$ Even though the first two countries are not part of the Euro area, Germany is the biggest in the Euro area.
} 
the European banking sector which contaminates the real activity. ${ }^{26}$ Corsetti et al. (2014) develop a New Keynesian DSGE model to show how the implementation of a procyclical fiscal policy during a sovereign debt crisis can lead to a belief-driven recession. Our model is not suitable to provide a full analysis of the sovereign debt crisis as done by Corsetti et al. (2014), given the absence of the public debt in the model. However, we can provide some explanation of the persistence of high term premium in the Euro area, measured as the difference between long-term government bond yields and short-term interest rates. Risk shocks, which explain almost half of the variance of the term premium at business cycle frequency in the US and almost three-quarters in the Euro area-see Table 2, are at the origin of the recent divergence in the term premium. ${ }^{27}$

The link between the sovereign debt crisis and risk shocks can be understood through a bank channel. Christiano and Ikeda (2014) explain that risk shocks can be interpreted as shocks on the riskiness of the business done by entrepreneurs, i.e. non-financial corporations, or by financial firms, since we consider households as the ultimate lenders. In the former case, there is no agency problem between households and financial intermediaries who lend to entrepreneurs with asymmetric information. In the latter case, information is

${ }^{26}$ Gennaioli et al. (2018) find a negative correlation between bank's exposure to sovereign risk and lending in 191 countries between 1998 and 2012. This stylized fact can be applied to the Euro area as Shambaugh (2012), Lane (2012), and Reichlin (2014) show in narratives of the European debt crisis. Acharya et al. (2014) and IMF (2013b) study the determinants of public debt costs and the interplay with the bank debt cost. Neri (2013) and ECB (2012) attempt to quantify the transmission of these tensions to the bank lending rates for the non financial corporations in the Euro area.

${ }^{27} \mathrm{An}$ increase in $\sigma$ causes an increase in the term premium because the fall of long-term interest rate, associated with the reduction in future consumption, is lower than the fall in short-term interest rate implied by the monetary policy rule in response to the recession. 


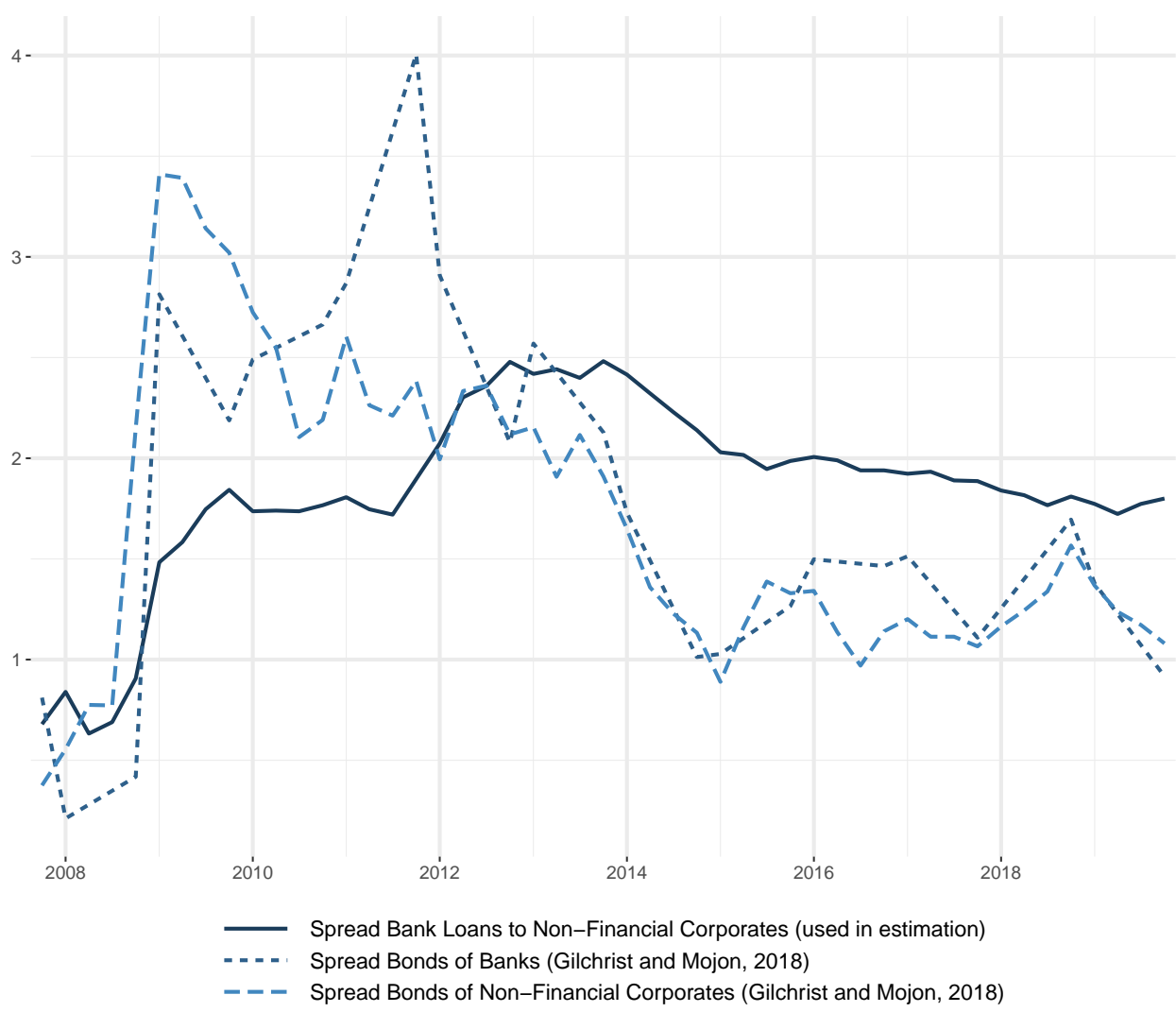

Figure 7 - Interest rates spread in percent (2007Q1-2019Q4)

asymmetric between households and financial intermediaries, but not between these and entrepreneurs. Using the second interpretation of the model, we establish a link between the financial distress of banks during the sovereign debt crisis in the Euro area and the high contribution of risk shocks in the 2011 recession: the high level of estimated idiosyncratic uncertainty concerns the risk of banks, which have been excessively exposed to sovereign bond risk.

In our estimation, the credit spread measures the cost of external finance for non-financial firms and not for banks as calculated by Gilchrist and Mojon (2018). The spreads for both the financial firms and the non-financial firms have increased in 2011 as shown in Figure 7 , but they have started diverging in 2012: it falls for banks whereas it remains high for nonfinancial corporations. The high value of credit spreads underscores the important role 
attributed to risk shocks in the persistence of Euro area weak growth. Further researches should be devoted to explaining the recent divergence between these two spreads and why the loan interest rate does not fall after 2012, contrary to the yield of financial corporate debt securities.

It is worth mentioning that Gilchrist and Mojon (2018) also report a fall in the credit spread for non financial corporations after 2012 when they consider the interest rate for corporate debt securities instead of the interest rate for bank loans-see Figure 7 . We want to test their different definition of credit spread. Figure .1 shows the contribution of risk shocks for the model estimated using the series of credit spreads constructed by Gilchrist and Mojon (2018). The simulated growth rate of real GDP is indeed slightly less negative after 2012 than for the benchmark estimation, but it does not alter our conclusion on the role of risk shocks in the double-dip recession. ${ }^{28}$ As discussed above, we choose the interest rate for bank loans instead of the interest rate for corporate debt securities given the high importance of bank credit when compared with debt securities in the external financing of non financial corporations-see ECB (2011).

\section{Conclusion}

The recent divergence between the Euro area and the US, abundantly commented in the public debate, will surely constitute an important area for future research. Why did the Euro area economy fall a second time in 2011 and not the US economy? We propose an answer based on the estimation of a DSGE model with financial frictions. According

\footnotetext{
${ }^{28}$ Since 2012, the blue bars depicted in Figure 3 are below the red line, associated with historical data, whereas they are above in Figure .1. See Table 3 for the complete variance decomposition when the model is estimated using the series of credit spreads constructed by Gilchrist and Mojon (2018).
} 
to our estimation, based on CMR methodology, risk shocks are central in explaining the divergence because they are at the origin of both the US recovery and the Euro area double-dip recession. The second financial recession of 2011 in the Euro area can be explained by the sovereign debt crisis that increased the risk in the financial sector given the "doom loop" between bank and sovereign debts. After 2015, a lower risk level in the financial sector can be attributed to the effects of the ECB's APP on the corporate credit market. Our analysis of the divergence ends in 2019, just before the COVID-19 pandemic outbreak which has messed up the world economy. The last estimates provided by the $\mathrm{IMF}^{29}$ suggest however substantial gaps in economic growth within economies with a recession of $-3.4 \%$ for the US economy against $-7.1 \%$ for the Euro area. We therefore can expect a deepening of the divergence described in this paper.

\section{References}

Acharya, V., Drechsler, I., and Schnabl, P. (2014). A pyrrhic victory? bank bailouts and sovereign credit risk. The Journal of Finance, 69(6):2689-2739.

Adjemian, S., Bastani, H., Juillard, M., Mihoubi, F., Perendia, G., Ratto, M., and Villemot, S. (2011). Dynare: Reference manual. Dynare Working Papers.

An, S. and Schorfeide, F. (2007). Bayesian analysis of DSGE models. Econometric Reviews, 26:113-172.

Arellano, C., Bai, Y., and Kehoe, P. J. (2019). Financial frictions and fluctuations in volatility. Journal of Political Economy, 127(5):2049-2103.

Baker, S., Bloom, N., Davis, S. J., and Van Reenen, J. (2012). Economic recovery and

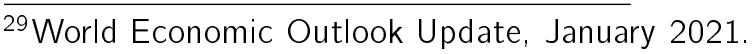


policy uncertainty in the US. VoxEU, October, 29th.

Bernanke, B., Gertler, M., and Gilchrist, S. (1999). The financial accelerator in a quantitative business cycle. Handbook of Macroeconomics, 1:1341-1393.

Bernanke, B. S. (1983). Irreversibility, uncertainty, and cyclical investment. Quarterly Journal of Economics, 98(1):85-106.

Bloom, N. (2009). The impact of uncertainty shocks. Econometrica, 77(3):623-685.

Bloom, N., Floetotto, M., Jaimovich, N., Saporta-Eksten, I., and Terry, S. J. (2018). Really uncertain business cycles. Econometrica, 86(3):1031-1065.

Cahn, C., Matheron, J., and Sahuc, J.-G. (2017). Assessing the macroeconomic effects of Itros during the great recession. Journal of Money, Credit and Banking, 49(7):14431482.

Cantor, R. and Varma, P. (2005). Determinants of recovery rates on defaulted bonds and loans for north american corporate issuers: 1983-2003. The Journal of Fixed Income, $14(4): 29-44$.

Carlstrom, C. and Fuerst, T. (1997). Agency costs, net worth, and business fluctuations: A computable general equilibrium analysis. The American Economic Review, 87(5):893910.

Christiano, L. and Ikeda, D. (2014). Leverage restrictions in a business cycle model. pages $15-16$.

Christiano, L., Motto, R., and Rostagno, M. (2008). Shocks, structures or monetary policies? The Euro Area and US after 2001. Journal of Economic Dynamics and Control, 32(8):2476-2506.

Christiano, L., Motto, R., and Rostagno, M. (2010). Financial factors in economics 
fluctuations. ECB working paper.

Christiano, L., Motto, R., and Rostagno, M. (2014). Risk shocks. American Economic Review, 104(1):27-65.

Christiano, L. J., Eichenbaum, M., and Evans, P. (2005). Nominal rigidities and the dynamic effects of a shock to monetary policy. Journal of Political Economy, 113(1):145.

Christiano, L. J., Eichenbaum, M. S., and Trabandt, M. (2015). Understanding the great recession. American Economic Journal: Macroeconomics, 7(1):110-67.

Coenen, G., Straub, R., and Trabandt, M. (2012). Fiscal policy and the Great recession in the Euro area. American Economic Review, 102(3):71-76.

Corsetti, G., Kuester, K., Meier, A., and Mueller, G. J. (2014). Sovereign risk and belief-driven fluctuations in the Euro area. Journal of Monetary Economics, 61:53-73.

Darracq Pariès, M., Sørensen, C. K., and Rodriguez-Palenzuela, D. (2011). Macroeconomic propagation under different regulatory regimes: Evidence from an estimated DSGE model for the Euro area. International Journal of Central Banking, 7(4):49-113.

De Fiore, F. and Uhlig, H. (2011). Bank finance versus bond finance. Journal of Money, Credit and Banking, 43(7):1399-1421.

De Fiore, F. and Uhlig, H. (2015). Corporate debt structure and the financial crisis. Journal of Money, credit and Banking, 47(8):1571-1598.

Del Negro, M., Eusepi, S., Giannoni, M., Sbordone, A., Tambalotti, A., Cocci, M., Hasegawa, R., and Linder, M. H. (2013). The FRBNY DSGE model. Federal Reserve Bank of New York Staff Reports.

ECB (2011). Financial integration in Europe. ECB Report. 
ECB (2012). Assessing the financing conditions for the Euro area private sector during the sovereign debt crisis. ECB Monthly Bulletin, August:77-95.

Fagan, G., Henry, J., and Mestre, R. (2001). An area-wide model for the euro area. ECB Working Paper.

Fatás, A. and Mihov, I. (2013). Recoveries. CEPR Discussion Papers.

Galí, J., Smets, F., and Wouters, R. (2012). Slow recoveries: A structural interpretation. Journal of Money, Credit and Banking, 44(s2):9-30.

Gennaioli, N., Martin, A., and Rossi, S. (2018). Banks, government bonds, and default: What do the data say? Journal of Monetary Economics, 98:98-113.

Gerali, A., Neri, S., Sessa, L., and Signoretti, F. (2010). Credit and banking in a DSGE model of the Euro area. Journal of Money, Credit and Banking, 42:107-141.

Gertler, M. and Karadi, P. (2011). A model of unconventional monetary policy. Journal of Monetary Economics, 58:17-34.

Gilchrist, S. and Mojon, B. (2018). Credit risk in the euro area. The Economic Journal, 128(608):118-158.

Gilchrist, S., Sim, J. W., and Zakrajšek, E. (2014). Uncertainty, financial frictions, and investment dynamics.

Grjebine, T., Szczerbowicz, U., and Tripier, F. (2018). Corporate debt structure and economic recoveries. European Economic Review, 101:77-100.

IMF (2013a). Assessing policies to revive credit markets. Global Financial Stability Report, October:63-104.

IMF (2013b). A new look at the role of sovereign credit default swaps. Global Financial 
Stability Report, April:57-92.

Khieu, H. D., Mullineaux, D. J., and Yi, H.-C. (2012). The determinants of bank loan recovery rates. Journal of Banking \& Finance, 36(4):923-933.

Kollmann, R., Pataracchia, B., Raciborski, R., Ratto, M., Roeger, W., and Vogel, L. (2016). The post-crisis slump in the euro area and the us: Evidence from an estimated three-region dsge model. European Economic Review, 88:21-41.

Kollmann, R., Ratto, M., Roeger, W., et al. (2013). Fiscal policy, banks and the financial crisis. Journal of Economic Dynamics and Control, 37(2):387-403.

Lane, P. (2012). The European sovereign debt crisis. Journal of Economic Perspectives, 26(3):49-68.

Lombardo, G. and McAdam, P. (2012). Financial market frictions in a model of the Euro area. Economic Modelling, 29(6):2460-2485.

Merola, R. (2015). The role of financial frictions during the crisis: An estimated dsge model. Economic Modelling, 48:70-82.

Mouabbi, S. and Sahuc, J.-G. (2019). Evaluating the macroeconomic effects of the ecb's unconventional monetary policies. Journal of Money, Credit and Banking, 51(4):831858.

Neri, S. (2013). The impact of the sovereign debt crisis on bank lending rates in the euro area. Bank of Italy occasional paper, (170).

Pisani-Ferry, J. (2014). The Euro crisis and its aftermath. Oxford University Press.

Quint, D. and Rabanal, P. (2014). Monetary and macroprudential policy in an estimated DSGE model of the Euro area. International Journal of Central Banking, 10(2):169236. 
Rajan, R. (2013). A step in the dark: Unconventional monetary policy after the crisis. Andrew Crockett Memorial Lecture, Bank for International Settlements.

Reichlin, L. (2014). Monetary policy and banks in the Euro area: The tale of two crises. Journal of Macroeconomics, 39, Part B:387 - 400.

Reinhart, C. M. and Rogoff, K. S. (2014). Recovery from financial crises: Evidence from 100 episodes. American Economic Review, 104(5):50-55.

Sala, L., Söderström, U., and Trigari, A. (2013). Structural and cyclical forces in the labor market during the Great recession: Cross-country evidence. NBER International Seminar on Macroeconomics, 9(1):345-404.

Shambaugh, J. C. (2012). The euro's three crises. Brookings Papers on Economic Activity, Spring:157-221.

Smets, F. and Wouters, R. (2003). An estimated dynamic stochastic general equilibrium model of the Euro area. Journal of the European Economic Association, 1(5):11231175.

Smets, F. and Wouters, R. (2005). Comparing shocks and frictions in US and Euro area business cycles: a Bayesian DSGE approach. Journal of Applied Econometrics, 20(2):161-183.

Smets, F. and Wouters, R. (2007). Shocks and frictions in US business cycles. American Economic Review, 97(3):586-606.

Stein, J. C. (2013). Restoring household financial stability after the Great recession: Why household balance sheets matter. Research symposium sponsored by the Federal Reserve Bank of St. Louis.

Taylor, J. B. (2014). The role of policy in the great recession and the weak recovery. 
American Economic Review, 104(5):61-66.

Townsend, R. (1979). Optimal contracts and competitive markets with costly state verification. Journal of Economic Theory, 21(2):265-93.

Villa, S. (2016). Financial Frictions In The Euro Area And The United States: A Bayesian Assessment. Macroeconomic Dynamics, 20(5):1313-1340.

von Heideken, Q. (2009). How important are financial frictions in the United States and the Euro area? The Scandinavian Journal of Economics, 111(3):567-596. 


\section{Appendix}




\section{Other estimation results}

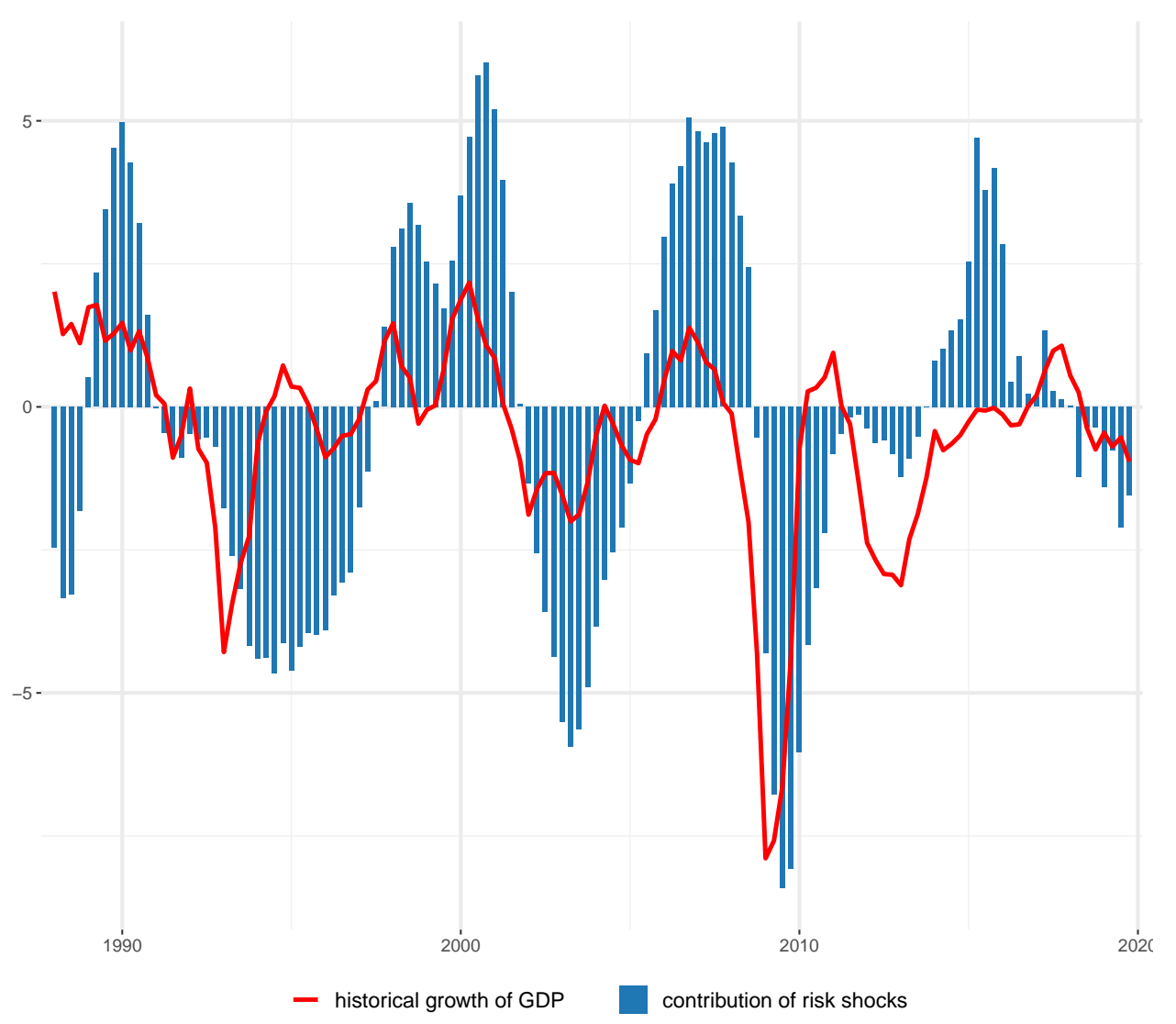

Figure .1 - Historical contribution of risk shocks to the growth rate of real GDP per capita with GM credit spread, year-on-year (1988Q1-2019Q4)

Note: The solid line is the historical growth of real GDP per capita (year-on-year). The "contribution of risk shocks" is the sum of the contributions to GDP fluctuations explained by anticipated and unanticipated components of the risk shocks. 


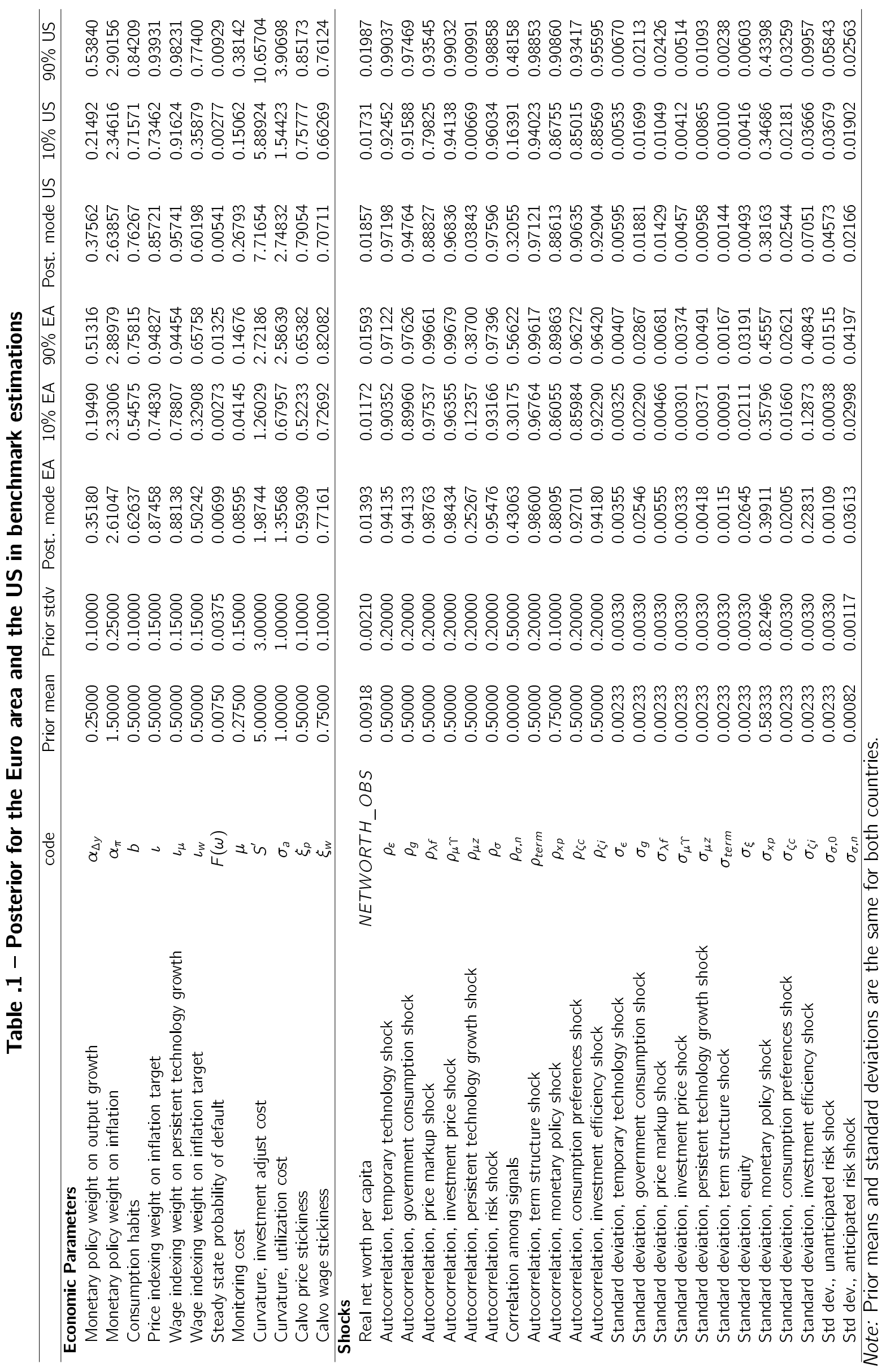




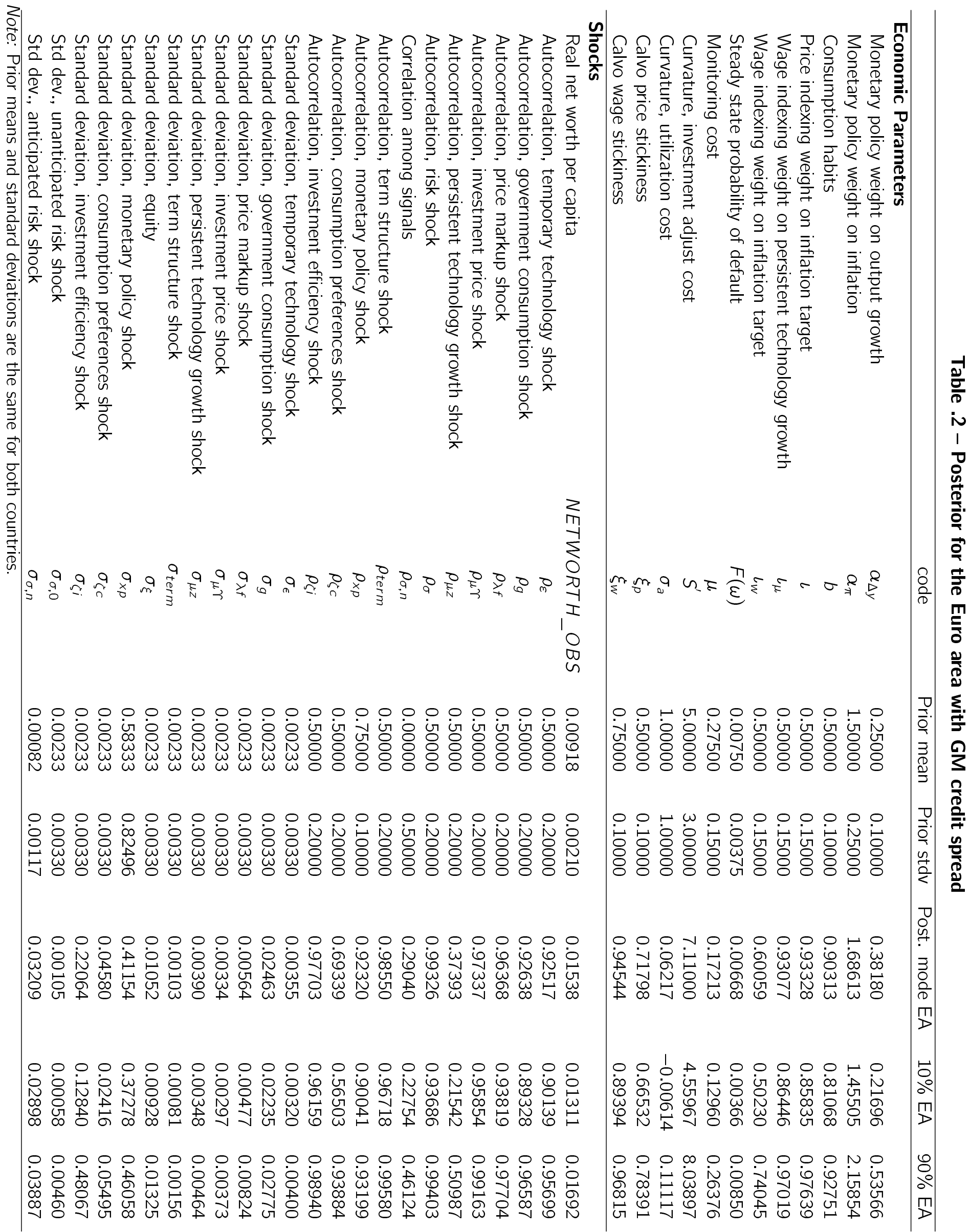


Table .3 - Variance decomposition at business cycle frequency (Percent) with GM credit spread

\begin{tabular}{llrrrrrrr}
\hline & risk & equity & investment & technology & markup & cons. pref. & mon. pol. & gov. cons. \\
\hline GDP & 64.15 & 1.47 & 9.31 & 1.01 & 1.10 & 5.95 & 4.33 & 12.66 \\
consumption & 2.79 & 0.07 & 0.47 & 2.43 & 2.49 & 86.83 & 4.91 & 0.00 \\
investment & 82.62 & 1.88 & 11.54 & 0.14 & 0.61 & 0.00 & 3.20 & 0.00 \\
credit & 43.09 & 46.25 & 6.19 & 0.89 & 2.95 & 0.01 & 0.62 & 0.00 \\
net worth & 34.47 & 5.54 & 55.70 & 0.18 & 0.83 & 0.00 & 3.26 & 0.00 \\
invest. price & 0.00 & 0.00 & 100.00 & 0.00 & 0.00 & 0.00 & 0.00 & 0.00 \\
wage & 0.10 & 0.00 & 0.08 & 72.86 & 26.95 & 0.01 & 0.01 & 0.01 \\
inflation & 0.95 & 0.03 & 2.12 & 21.23 & 75.15 & 0.17 & 0.20 & 0.04 \\
hours worked & 70.34 & 1.28 & 13.59 & 1.77 & 1.97 & 4.24 & 4.33 & 2.47 \\
interest rate & 6.65 & 0.15 & 4.13 & 8.50 & 32.69 & 0.43 & 47.29 & 0.13 \\
credit spread & 82.45 & 2.85 & 13.28 & 0.07 & 0.27 & 0.00 & 1.08 & 0.00 \\
term structure & 9.84 & 0.13 & 3.94 & 5.88 & 18.36 & 0.24 & 25.55 & 0.06 \\
\hline
\end{tabular}

Note: For each observed variable in row, the "risk" column is the sum of the variance explained by anticipated and unanticipated components of the risk shocks, the "investment" column is the sum of the variance explained by investment price and investment efficiency shocks and the "technology" column is the sum of the variance explained by temporary technology and persistent technology growth shocks. We omit the contributions of inflation target and term structure shocks. Numbers in each row may not add up to 100 as we ignore the correlation between the shocks when we add explained variances. Business cycle frequency is measured with HP filter $(\lambda=1600)$. 